https://doi.org/10.48009/1_iis_2010_585-588

\title{
STUDENTS' USE OF MOBILE DEVICES: AN EXPLORATORY SURVEY IN AN INTRODUCTORY COMPUTER INFORMATION SYSTEM CLASS.
}

\author{
Kamal K. Hingorani, Alabama State University, khingorani@alasu.edu \\ Donald Woodard, Alabama State University, dwoodard@alasu.edu
}

\begin{abstract}
Use of mobile devices in classrooms is posing a major challenge to instructors. This exploratory research surveyed 181 students enrolled in the introductory CIS class on the use of mobile devices including cell phones. The results were compared with a similar survey conducted on teens by the Pew Research Center. Major similarities and differences between the results of the two surveys are presented.
\end{abstract}

Keywords: Information Technology (IT), Cell Phones Usage and Civility, Mobile Devices, Classroom.

\section{INTRODUCTION}

For years, educators have been clamoring to put technology in the hands of young students, but of late there has been a noticeable shift in this policy. In 2008, the University of Chicago Law School turned off Internet access in classrooms in order to ensure the value of the classroom experience [9]. At the University of Oklahoma, Professor Kieran Mullen became an Internet sensation when a student recorded him freezing a laptop in liquid nitrogen and shattering it. In his web page, the professor however clarified that the laptop was a plant and was nonfunctional before freezing but the episode did help him improve students' attention in his classroom [6].

In a recent commencement speech at Hampton University in Virginia, President Obama lamented the tendency of popular electronic devices to simply entertain and divert, rather than educate [10]. The president further added: "With iPods and iPads; Xboxes and PlayStations...information becomes a distraction, a diversion, a form of entertainment, rather than a tool of empowerment, rather than the means of emancipation."

The cell phone has revolutionized the way we live and communicate. During 2009, over 1.2 billion cell phones were sold world-wide. There are over 270 million cell-phone users in the United States and 82 percent of them do not leave their homes without their devices.
Nearly all university students own a cell-phone and this device has impacted their social life. Use of cell phones by students in the classroom is also proving a major challenge to most professors. Today, many syllabi contain statements banning the use of cell phone in the classroom and many universities have also issued written policies to this effect.

\section{Pew Research Center's Research on Teens and Mobile Phones}

The Pew Research Center, a nonpartisan "fact tank" that provides information on the issues, attitudes and trends shaping America and the world has been conducting longitudinal surveys on teens and mobile phones. The survey began in 2004 and the last report that contained the results of survey of 800 teens conducted in 2009 was released on April 20, 2010 [4].

The major findings of this survey were as under:

- The mobile phone has become the favored communication hub for the majority of teens.

- Girls more fully embrace most aspects of cell phone-based communication.

- One in three teens sends more than 100 text messages a day, or 3000 texts a month.

- Cell phones are not just about calling or texting with expanding functionality, phones have become multimedia recording devices and pocket-sized internet connected computers.

Our research was conducted to survey students enrolled in the introductory CIS class on their use of mobile devices and the internet. Special emphasis was laid on cell-phones so that the data could be compared to a nation-wide study conducted on the use of cell-phones by teenagers.

\section{RESEARCH METHODOLOGY}

This study was oriented towards freshmen and sophomore students enrolled in the introductory CIS class. This class was selected so that we could compare the results with those reported by the Pew research center on their survey of teenagers.

The survey was designed in-house using ASP.Net and was administered on the Internet. A total of 181 
students from eight different sections of the class participated in the survey. The survey had a total of 25 questions that included some demographic questions. The demographics of the survey respondents are shown in Table 1.

Table 1. Demographics of Survey Respondents

\begin{tabular}{|l|l|l|l|}
\hline \multicolumn{2}{|l|}{ Characteristics } & N & \% \\
\hline Gender & Male & 88 & $48.6 \%$ \\
\hline & Female & 93 & $51.4 \%$ \\
\hline Residence & On Campus & 105 & $58.0 \%$ \\
\hline & Off Campus & 76 & $42.0 \%$ \\
\hline Age-years & $<18$ & 1 & $0.6 \%$ \\
\hline & 18 & 22 & $12.2 \%$ \\
\hline & 19 & 20 & $11.0 \%$ \\
\hline & 20 & 49 & $27.1 \%$ \\
\hline & 21 & 46 & $25.4 \%$ \\
\hline & 22 & 27 & $14.9 \%$ \\
\hline & $>22$ & 16 & $8.8 \%$ \\
\hline Classification & Unknown & 7 & $3.9 \%$ \\
\hline & FR & 65 & $35.9 \%$ \\
\hline & SO & 71 & $39.2 \%$ \\
\hline & JR & 26 & $14.4 \%$ \\
\hline & SR & 12 & $6.6 \%$ \\
\hline & Liberal Arts & 41 & $22.7 \%$ \\
\hline & Business & 85 & $47.0 \%$ \\
\hline & Education & 4 & $2.2 \%$ \\
\hline & Sciences & 49 & $27.0 \%$ \\
\hline & Undecided & 2 & $1.1 \%$ \\
\hline & & & \\
\hline
\end{tabular}

RESULTS

Personal ownership of electronic devices is shown in Table 2. All the 181 students surveyed owned a cellphone. Ownership of PCs including laptops was $90 \%$. Only $28 \%$ of the students owned a portable game console

Table 2. Ownership of electronic devices

\begin{tabular}{|l|l|l|}
\hline Ownership & N & \% \\
\hline Cell Phone & 181 & $100 \%$ \\
\hline PC/Laptop & 163 & $90 \%$ \\
\hline MP3 Player & 139 & $77 \%$ \\
\hline Game Console & 99 & $55 \%$ \\
\hline Portable Game Console & 51 & $28 \%$ \\
\hline
\end{tabular}

Volume XI, No. 1, 2010
Over $85 \%$ of students accessed the Internet several times a day while the remaining $15 \%$ accessed it between 3-5 days/week as shown in Table 3.

Table 3. Frequency of Internet Access.

\begin{tabular}{|l|l|l|}
\hline Frequency & $\mathbf{N}$ & $\mathbf{\%}$ \\
\hline Several Times a day & 154 & $85 \%$ \\
\hline 3-5 days a week & 27 & $15 \%$ \\
\hline
\end{tabular}

All the 18 students who did not own a PC had the lower frequency for Internet access.

The students' response on the use of Internet for various activities is detailed in Table 4.

Table 4: Use of Internet

\begin{tabular}{|l|l|l|}
\hline Do you use the internet to & N & \% \\
\hline $\begin{array}{l}\text { use an online social networking } \\
\text { site like Facebook }\end{array}$ & 158 & $95 \%$ \\
\hline $\begin{array}{l}\text { to get news or information } \\
\text { about current events or politics. }\end{array}$ & 172 & $87 \%$ \\
\hline $\begin{array}{l}\text { to buy things online, such as } \\
\text { books, clothing, or music }\end{array}$ & 151 & $83 \%$ \\
\hline $\begin{array}{l}\text { to look online for health, } \\
\text { dieting, or physical fitness } \\
\text { information som }\end{array}$ & 132 & $73 \%$ \\
\hline $\begin{array}{l}\text { to share something online that } \\
\text { you created yourself, such as } \\
\text { your own artwork, photos, or } \\
\text { videos }\end{array}$ & 127 & $72 \%$ \\
\hline $\begin{array}{l}\text { to look for information online } \\
\text { about a health topic that's hard } \\
\text { to talk about }\end{array}$ & 79 & $70 \%$ \\
\hline $\begin{array}{l}\text { to take material you find online } \\
\text { - like songs, text or images - } \\
\text { and remix it into your own } \\
\text { artistic creation }\end{array}$ & 131 & $66 \%$ \\
\hline $\begin{array}{l}\text { to create or work on your own } \\
\text { online journal or blog }\end{array}$ & 119 & $44 \%$ \\
\hline to use Twitter & 74 & $41 \%$ \\
\hline $\begin{array}{l}\text { to visit virtual worlds such as } \\
\text { Gaia, Second Life or Habbo } \\
\text { Hotel }\end{array}$ & 29 & $16 \%$ \\
\hline
\end{tabular}

The data reveals the importance of Facebook to the student community with over $95 \%$ of the students using the internet to access this social-networking site. The use of Twitter was relatively low with only $41 \%$ accessing this social-media site. Only $16 \%$ of the students used the internet for accessing virtual worlds. This data would suggest that the introductory CIS course should include exercises on Twitter and virtual worlds. We, as a university, have decided that 
every instructor in the class would tweet on CIS topics every week and all students will have to follow their instructor on Twitter.

Of the various mobile devices, the cell phone is ubiquitous [8]. All the students in the survey owned a cell-phone. Their use of cell phone for various activities is shown in Table 5. The responses for these items were measured on a 5-point Likert-like scale (Every Day, Several times a week, At least once a week, Less than once a week, Never).

Table 5: Students' use of cell phone.

\begin{tabular}{|c|c|c|c|c|}
\hline \multirow[b]{2}{*}{ Use } & \multicolumn{2}{|c|}{ Daily } & \multicolumn{2}{|c|}{ Never } \\
\hline & $\mathbf{N}$ & $\%$ & $\mathbf{N}$ & $\%$ \\
\hline $\begin{array}{l}\text { send or receive } \\
\text { text messages }\end{array}$ & 158 & $87.3 \%$ & 2 & $1.1 \%$ \\
\hline play music & 87 & $48.1 \%$ & 21 & $11.6 \%$ \\
\hline $\begin{array}{l}\text { use a Social } \\
\text { Networking site }\end{array}$ & 78 & $43.1 \%$ & 46 & $25.4 \%$ \\
\hline $\begin{array}{l}\text { send or receive } \\
\text { email }\end{array}$ & 77 & $42.5 \%$ & 52 & $28.7 \%$ \\
\hline $\begin{array}{l}\text { send or receive } \\
\text { pictures }\end{array}$ & 65 & $35.9 \%$ & 11 & $6.1 \%$ \\
\hline $\begin{array}{l}\text { use an } \\
\text { application that } \\
\text { you installed }\end{array}$ & 65 & $35.9 \%$ & 52 & $28.7 \%$ \\
\hline take a picture & 58 & $32.0 \%$ & 9 & $5.0 \%$ \\
\hline $\begin{array}{l}\text { send or receive } \\
\text { Instant Messages }\end{array}$ & 58 & $32.0 \%$ & 54 & $29.8 \%$ \\
\hline play a game & 44 & $24.3 \%$ & 46 & $25.4 \%$ \\
\hline record a video & 37 & $20.4 \%$ & 30 & $16.6 \%$ \\
\hline $\begin{array}{l}\text { send or receive a } \\
\text { video }\end{array}$ & 36 & $19.9 \%$ & 44 & $24.3 \%$ \\
\hline buy a product & 33 & $18.2 \%$ & 44 & $24.3 \%$ \\
\hline
\end{tabular}

The above table suggests that cell phones are not just about calling or texting - with expanding functionality, phones have become multimedia recording devices and pocket-sized internet connected computers.

Ninety-nine percent of the students surveyed used text messaging on their cell phones with over eightyseven using this feature daily. The use of cell phones for buying products was relatively low. Table 6 shows the numbers of text messages sent every day by students. Over $48.6 \%$ of the students surveyed sent more than 100 messages per day using their cell phones.
Table 6: Students' use of cell phone for texting.

\begin{tabular}{|l|l|l|}
\hline \# Texts/day & N & \% \\
\hline More than 200 & 58 & $32.0 \%$ \\
\hline $101-200$ & 30 & $16.6 \%$ \\
\hline $51-100$ & 36 & $19.9 \%$ \\
\hline $21-50$ & 26 & $14.4 \%$ \\
\hline $11-20$ & 18 & $9.9 \%$ \\
\hline $1-10$ text & 11 & $6.1 \%$ \\
\hline None & 2 & $1.1 \%$ \\
\hline
\end{tabular}

The use of cell phones in the classroom is shown in Table 7. Only $6 \%$ of the students had never sent or received text messages in the classroom. Over 67\% of the students had made or received calls in the classroom. This data reveals the extent of challenges facing CIS instructors as we try to get their students' undivided attention.

Table 7: Students' use of cell phone at school

\begin{tabular}{|l|l|l|l|}
\hline \multirow{2}{*}{ Response } & \multicolumn{3}{|l|}{ How often do you (at school) } \\
\cline { 2 - 4 } & $\begin{array}{l}\text { keep cell } \\
\text { phone on }\end{array}$ & $\begin{array}{l}\text { make or } \\
\text { receive } \\
\text { calls in } \\
\text { class }\end{array}$ & $\begin{array}{l}\text { send or } \\
\text { receive } \\
\text { text } \\
\text { messages } \\
\text { in class }\end{array}$ \\
\hline No Response & $3(2 \%)$ & $8(4 \%)$ & $5(3 \%)$ \\
\hline $\begin{array}{l}\text { Several times } \\
\text { a Day }\end{array}$ & $138(76 \%)$ & $50(28 \%)$ & $105(58 \%)$ \\
\hline $\begin{array}{l}\text { At least once } \\
\text { a Day }\end{array}$ & $19(10 \%)$ & $18(10 \%)$ & $26(14 \%)$ \\
\hline $\begin{array}{l}\text { A few times a } \\
\text { week }\end{array}$ & $6(3 \%)$ & $16(9 \%)$ & $22(12 \%)$ \\
\hline Less often & $5(3 \%)$ & $37(20 \%)$ & $12(7 \%)$ \\
\hline Never & $10(6 \%)$ & $52(29 \%)$ & $11(6 \%)$ \\
\hline
\end{tabular}

It has been widely reported that cell phone has impacted the social life of most people [2, 3, 7]. Table 8 shows the different methods by which students in the survey socialized with their friends. Texting and calling on the cell phone appeared to be the preferred way of socializing with friends in the college campus. Over $85 \%$ of the students texted their friends on a daily basis while only $44.8 \%$ of the students physically socialized with their friends outside school. 
Table 8: Impact of cell phone on socializing

\begin{tabular}{|l|l|l|l|l|}
\hline & \multicolumn{2}{|l|}{ Daily } & \multicolumn{2}{l|}{ Never } \\
\hline $\begin{array}{l}\text { About how often } \\
\text { do you }\end{array}$ & $\mathbf{N}$ & $\%$ & $\mathbf{N}$ & $\%$ \\
\hline $\begin{array}{l}\text { send text messages } \\
\text { to each other }\end{array}$ & 155 & $85.6 \%$ & 3 & $1.7 \%$ \\
\hline $\begin{array}{l}\text { talk to friends on } \\
\text { your cell phone }\end{array}$ & 128 & $70.7 \%$ & 2 & $1.1 \%$ \\
\hline $\begin{array}{l}\text { spend time with } \\
\text { friends, doing social } \\
\text { activities outside of } \\
\text { school }\end{array}$ & 81 & $44.8 \%$ & 3 & $1.7 \%$ \\
\hline $\begin{array}{l}\text { send messages } \\
\text { through social } \\
\text { networking sites }\end{array}$ & 75 & $41.4 \%$ & 10 & $5.5 \%$ \\
\hline $\begin{array}{l}\text { talk to friends on a } \\
\text { landline or home } \\
\text { telephone }\end{array}$ & 60 & $33.1 \%$ & 42 & $23.2 \%$ \\
\hline $\begin{array}{l}\text { send instant } \\
\text { messages to friends }\end{array}$ & 58 & $32.0 \%$ & 37 & $20.4 \%$ \\
\hline $\begin{array}{l}\text { send email to each } \\
\text { other }\end{array}$ & 30 & $16.6 \%$ & 46 & $25.4 \%$ \\
\hline
\end{tabular}

Since this was an exploratory study, t-tests (Anova for groups of more than two) were conducted to find any differences in responses for genders, classification, and college. No significant difference was noticed in any of the variables. The items on Likert-like scale were opertionalized using the following scale: every day (5), several times a week (4), at least once a week (3), less than once a week (2), never (1). We do not report the mean and standard deviation here because this was an exploratory research.

\section{CONCLUSIONS}

The survey on teens conducted by the Pew research had reported that girls more fully embraced all the features of the cell phones. In this research, we did not find any difference between the two genders. Both the genders seem to have fully embraced all the features of the cell phones at the university level.

Further, it was established that most students have smart phones and although texting is the most important feature on a cell phone, students used the device as multimedia recording devices and pocketsized internet connected computers. A large number of students use the cell phones for texting in the classroom and some of them also receive voice calls during class. This finding should help reinforce universities resolve for banning the use of cell phones in the class room. The millennials (generation of people born from 1977 to 2002) are of the opinion that they can multi-task and use of the cell phones in the classroom should not offend professors [1]. But as instructors we know that it's impossible to pay attention to a lecture and use the cell phone at the same time. Further, as instructors we have also to teach our students what's appropriate in the workplace and most workplace do not appreciate you using the cell phone when you are working.

\section{REFERENCES}

1. Brandt, Jessica. and Heller, Michael (2007). Learning Unplugged: Using Cell Phones in Language and Culture Courses, Paper presented at American Council on the Teaching of Foreign Languages, San Antonio, TX, Nov 12, 2007

2. Ehow (2010). Social Disadvantages of Mobile Phones, http://www.ehow.com/list_6325088 _social-disadvantages-mobile-phones.html Accessed on April 10, 2010.

3. Harris Interactive. (2008) A Generation unplugged - Research Report. Harris Interactive. http://files.ctia.org/pdf/HI_TeenMobileStudy_ ResearchReport.pdf Accessed January 10, 2009.

4. Lenhart, Amanda, Ling, Rich and Campbell, Scott (2010) Teens and Mobile Phones, Pew Research Foundation, Washington, D.C.

5. Ling, Rich. (2008). New Tech, New Ties: How mobile communication is reshaping social cohesion. Cambridge: MIT Press.

6. Mullen, Kieran (2010). Kieran Mullen's Home page, http://www.nhn.ou.edu/ kieran/ Accessed on April 10, 2010.

7. Ran Wei, Ven-Hwei Lo (2006) Staying connected while on the move: Cell phone use and social connectedness New Media Society Feb 01, 2006; 8: 53-72.

8. Silk, Matt (2010). Marketing to the Ubiquitous Cellphone, E-Commerce Times, Feb. 23, 2010.

9. University of Chicago (2008). University of Chicago Law School eliminates Internet access in some classrooms http://news.uchicago.edu /news.php?asset id=1329. Accessed April 10, 2010.

10. White House (2010). Remarks by the President at Hampton University Commencement, May 9, 2010, http://www.whitehouse.gov/the-pressoffice/remarks-president-hampton-universitycommencement. Accessed May 10, 2010. 